\title{
The chimeric CYP21P/CYP21 gene and 21-hydroxylase deficiency
}

Received: 10 October 2003/ Accepted: 18 November 2003/Published online: 17 January 2004

(C) The Japan Society of Human Genetics and Springer-Verlag 2004

\begin{abstract}
The chimeric $C Y P 21 P / C Y P 21$ gene is a consequence of a $26-$ or $32-\mathrm{kb}$ deletion in the $C 4-C Y P 21$ repeat module of $C Y P 21 P$, tenascin A $(X A)$, serine/ threonine nuclear protein kinase $(R P 2)$, and the $C 4 B$ and $C Y P 21$ genes in congenital adrenal hyperplasia (CAH) with steroid 21-hydroxylase deficiency. To date, there have been three distinct chimeras found in $\mathrm{CAH}$ patients in ethnic Chinese. Initiation for production of these molecules is proposed to be chi-like sequences and a minisatellite consensus existing in several noncoding regions in $C Y P 21$ genes. These molecules have the 5 ' end of the $C Y P 21 P$-specific sequence in common but differ in the 3 ' end of $C Y P 21$-specific genes. In addition, there appears to be a $3.2-\mathrm{kb}$ fragment generated by $T a q$ I digestion, which leads to allele dropout in PCR amplification for detecting the aberrant splicing site of the IVS2 $-12 \mathrm{~A} / \mathrm{C}>\mathrm{G}$ mutation at nucleotide (nt) 655 in the $C Y P 21$ gene. Therefore, the chimeric CYP21P/CYP21 cannot be detected by conventional methods. It has been demonstrated that a PCR product amplified with allele-specific primers covering tenascin $\mathrm{B}(T N X B)$ to the 5 ' end of the CYP21 gene combined with Southern analysis by Ase I and Nde I digestion may be used for identifying the chimera in the CYP21 gene.
\end{abstract}

Keywords Recombination - Deletion C Chi-like sequence $\cdot$ Minisatellite consensus sequence Chimera $\cdot$ RCCX module ' C4-CYP21 repeat module - $C Y P 21$. $\mathrm{CAH}$

H.-H. Lee

King Car Food Industrial Co., Yuan-Shan Research Institute,

326 Yuan-Shan Road, Sec. 2,

Yuanshan, 264 Ilan, Taiwan,

Republic of China

E-mail: hhlee@ms2.kingcar.com.tw

Tel.: + 886-3-9229000

Fax: + 886-3-9228030

\section{Introduction}

Congenital adrenal hyperplasia (CAH) is a common autosomal-recessive disorder caused mainly by defects in the steroid 21-hydroxylase (CYP21) gene. More than $90 \%$ of CAH cases are caused by mutation of the CYP21 gene (White and Speiser 2000). To date, 72 different CYP21 mutations have been reported (Human Gene Mutation Database 2003), among which 57 are spontaneous mutations. The remaining 15 mutations (Lee 2001) are believed to be products of intergenic recombinations of DNA sequences between the CYP21 gene and the highly homologous $C Y P 21 P$ pseudogene. These mutations can be identified by allele-specific oligonucleotide (ASO) (Speiser et al. 1994) and reverse dot-blot hybridizations (Yang et al. 2001), direct DNA sequencing (Tajima et al. 1993), PCR/ligase (Day et al. 1995), and the amplification-created restriction site (ACRS) method (Lee et al. 1996). For some unknown defective loci somewhere within the CYP21 gene, SSCP (Tajima et al. 1993; Lee et al. 1998) and denatured gradient gel electrophoresis (DGGE) (Ohlsson et al. 1999) may be applied to possibly find novel mutations in the CYP21 gene. However, all these applications for mutational detection should be carried out using the functional CYP21 gene. Therefore, the primary PCR product of the CYP21 gene has to be prepared by differential PCR amplification to eliminate any $C Y P 21 P$ contamination prior to mutational analysis. Most primary PCR products are derived by multiple allele-specific primer sets to generate the $C Y P 21$ gene in two PCR fragments using two-to-three-step PCR amplification (Day et al. 1996; Ordonez-Sanchez et al. 1998). For convenience and for amplification efficiency, a single, complete $C Y P 21$-specific amplification performed in a single reaction mixture is used (Lee et al. 1996). This PCR product contains the entire CYP21 gene, which can be cloned and characterized by an expression analysis (Lee and Chang 2001).

Identification of the $30-\mathrm{kb}$ gross gene deletion (White et al. 1984) encompassing the $C 4 A$ and $C Y P 21$ genes in the 
C4-CYP21 repeat module was controversial in the past (Miller 1988; White et al. 1988; Morel et al. 1989), even though the deletion had been demonstrated by pulse field electrophoresis (Collier et al. 1989). The ambiguity was mainly caused by the lack of detailed information on the extent of gene conversion or deletion in the C4-CYP21 repeat module or RCCX module (Shen et al. 1994) in chromosome 6p21.3. This module includes $C Y P 21 P, X A$ (Gitelman et al. 1992), the serine/threonine nuclear protein kinase $R P$ (Yang et al. 1998), C4, CYP21, and tenascin B (TNXB) (Bristow et al. 1993) genes (Fig. 1A). The $\mathrm{C} 4$ protein is coded by two genes, $C 4 A$ and $C 4 B$. Long gene $(20.4 \mathrm{~kb})$ or short gene $(14.1 \mathrm{~kb})$ of the $C 4$ is due to the presence of an endogenous retrovirus sequence (6.7 kb), HERV-K (C4), in intron 9 (Yu 1991). TNXB, in the downstream $C Y P 21$ gene, is partially duplicated in the downstream $C Y P 21 P$ gene, where it is termed $X A$ gene (TNXA). Both $X A$ and $T N X B$ are transcribed on the opposite strand. The $R P$ gene contains two duplicated genes, $R P 1$ and $R P 2$. The $R P 2$ gene is truncated and corresponding to $R P 1$ adjacent to TNXA (Yang et al. 1999). These tandemly arranged genes, CYP21P-XA$R P 2-C 4 B-C Y P 21-T N X B$, are designated as the RCCX module. At present, such a deletion is considered to result from an unequal crossover in meiosis occurring in $20 \%$ of alleles in most populations (White and Speiser 2000). However, the population frequency is dependent on the population studied (White and Speiser 2000). Three reports (Levo and Partanen 1997; Koppens et al. 2000; L'Allemand et al. 2000) pointed out that such a gross 30kb deletion consisted of a fused $C Y P 21$ gene, with its 5' and 3' ends corresponding to $C Y P 21 P$ and $C Y P 21$ respectively, and the product appearing as a 3.2-kb Taq I fragment in Southern blot analysis. In a recent study (Lee et al. 2003a), it demonstrated that such a $30-\mathrm{kb}$ gene deletion in fact is a chimeric $C Y P 21 P / C Y P 21$ formation caused by multiple gene deletions, including $X A, R P 2$, and $C 4 B$, and between unequal parts of the $C Y P 21 P$ and CYP21 genes in the C4-CYP21 repeat module (Fig. 1A). Such a gene deletion or gene conversion is traditionally detected by Southern blotting with multiple isotopelabeled probes and RFLP analysis; Taq I generates the $3.7-\mathrm{kb}$ (functional) and 3.2-kb (pseudogene) fragments, while $B g l$ II produces the $11-\mathrm{kb}$ (functional) and $12-\mathrm{kb}$ (pseudogene) fragments. These two approaches to fragment analysis have been used since 1984 (White et al. 1984; Donohoue et al. 1989; Koppens et al. 2000; L'Allemand et al. 2000). However, the method is laborious and indirect, and densitometric screening of fragments is error prone, although a nonisotopic Southern procedure was later described (Krone et al. 1998).

\section{Causes of the formation of the chimeric CYP21P/CYP21 gene}

Basically, the chimera features fused genes. In the case of P450c21, chimeric $C Y P 21 P / C Y P 21$ is formed by recombination of the duplicated $C Y P 21 P$ and $C Y P 21$ genes, but the cause of formation is unclear. However, several possibilities have been proposed:

Proximity to the human major histocompatibility complex (MHC)

In order to increase diversity of transplantation antigens and to maximize versatility of immune responses in humans, there is a high recombination rate in the MHC of the HLA complex. Both the CYP21P and $C Y P 21$ genes are on chromosome 6p21.3, adjacent to and alternating with the $C 4 A$ and $C 4 B$ genes encoding the fourth components of the serum complement (White et al. 1984), located within the HLA complex. As a result, the frequency of recombination events between these two genes is relatively high in human populations.

Fig. 1 A Strategy for identification of the chimeric $C Y P 21 P$ $C Y P 21$ in the RCCX module of the human histocompatibility (MHC) class III gene. The structure of the normal gene is shown in the white box; the black box represents a nonfunctional gene $(C Y P 21 P$ and $X A)$ or a different functional gene $(C 4 A)$. The deleted region of the RCCX module is indicated by a solid line, which represents a 26- or 32-kb deletion as described in the text published previously (Lee et al. 2003a). The chimeric CYP21P/ CYP21 is indicated by a half-white, half-black box. A 120-bp deletion in exon 36 of the TNXA gene and 707-714delGAGACTAC in the CYP21P gene are marked with an asterisk (*). Vertical arrows show the location of the restriction endonuclease cleavages. Deletion of the $X A, R P 2$, and $C 4 B$ genes led to the formation of a chimeric $C Y P 21 P / C Y P 21$ gene in a 9.3-kb fragment digested by AseI and NdeI endonucleases by Southern analysis, which was described previously (Lee et al. 2003a). B Restriction analysis of the amplification-created restriction site (ACRS) amplification product (Lee et al. 1996) and the map for detection of mutational loci in three $\mathrm{CAH}$ carriers with distinct chimeric $C Y P 21 P / C Y P 21$. The three distinct chimeras identified were designated $\mathrm{CH}-1, \mathrm{CH}-2$, and $\mathrm{CH}-3$. ACRS analysis was carried out on $2.5 \%$ Metaphor (FMC Bioproducts, USA). The ACRS primers used for the detection of P30L (a), IVS2 -12A/C > G $(b 1), \mathrm{I} 172 \mathrm{~N}(c), \mathrm{I} 236 \mathrm{~N}(d), \mathrm{V} 281 \mathrm{~L}$ $(g)$, Q318X (j1), and R356 W (j2) have been described previously (Lee et al. 1996; 2002). On the gel, lanes 2, 6, 10, 14, 18, 22, and 25 were a carrier with $\mathrm{CH}$-1. Lanes 3, 7, 11, 15, 19, 23, and 26 were a carrier with $\mathrm{CH}-2$. Lanes $4,8,12,16,20,24$, and 27 were a carrier with $C H-3$. Each amplification product was either untreated ("'-" lanes) or treated ("+ ") with an appropriate restriction enzyme $(R E)$ (Lee et al. 1996). The marker used was a 100-bp molecular ladder (lane " $m k$ "). The schematic representation is a result of three identified chimeras detected by the ACRS method. Exons for the CYP21P and CYP21 genes are shown as solid blocks and open boxes respectively. The vertical arrow indicates the position of the locus corresponding to the $2.5 \%$ metaphor analysis. A horizontal arrow indicates the position of the chi-like sequence and the minisatellite consensus. C A schematic diagram of the strategy for PCR amplification of a $6.2-\mathrm{kb}$ fragment by allele-specific primers (CYP779f/Tena 36F2) encompassing the TNXB gene to the CYP21 gene (Lee et al. 2003a, 2003b). The structure of the CYP21 and $\mathrm{C} 4 \mathrm{~B}$ genes is shown by a white box, while the black box represents the $C 4 A$ gene and exons of the TNXB gene. The chimeric $C Y P 21 P /$ $C Y P 21$ gene is indicated as described in A. Horizontal arrows represent the direction and location of the primers CYP779f and Tena36F2. Primer Tena36F2 is located in exon 36 of the TNXB gene in which a 120 -bp fragment deleted in $T N X A$ is marked by an asterisk (*) 
Homologous recombination

Because the exon sequence of the $C Y P 21 P$ pseudogene shares $98 \%$ nucleotide sequence homology with functional CYP21 (Higashi et al. 1986; White et al. 1986), homologous recombination of misalignment may occur at meiosis (Tusie-Luna and White 1995). It has been noted that the region between intron 2 and the 3 ' end of exon 3 in
$C Y P 21$ is considered a hotspot for recombinations and microconversions (Tusie-Luna and White 1995).

Initiation by the existence of a chi-like sequence and tandem-repetitive minisatellite consensus

Sequences such as chi (GCTGGTGG; Smith et al. 1981) and the tandem-repetitive minisatellite consensus

A

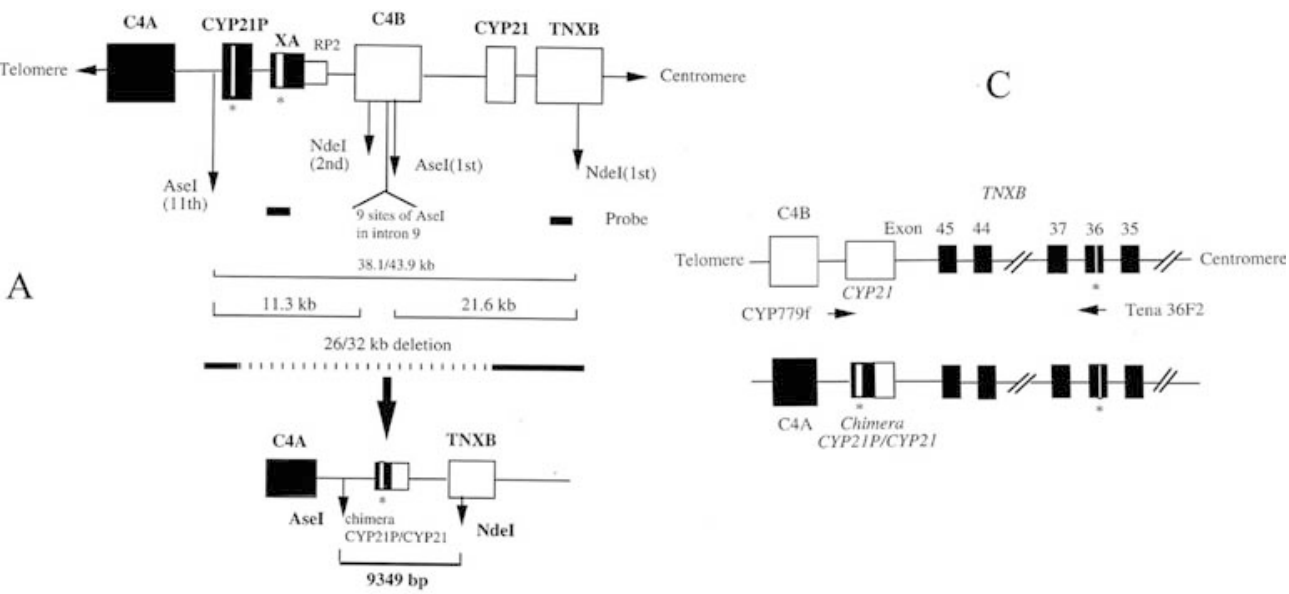

B
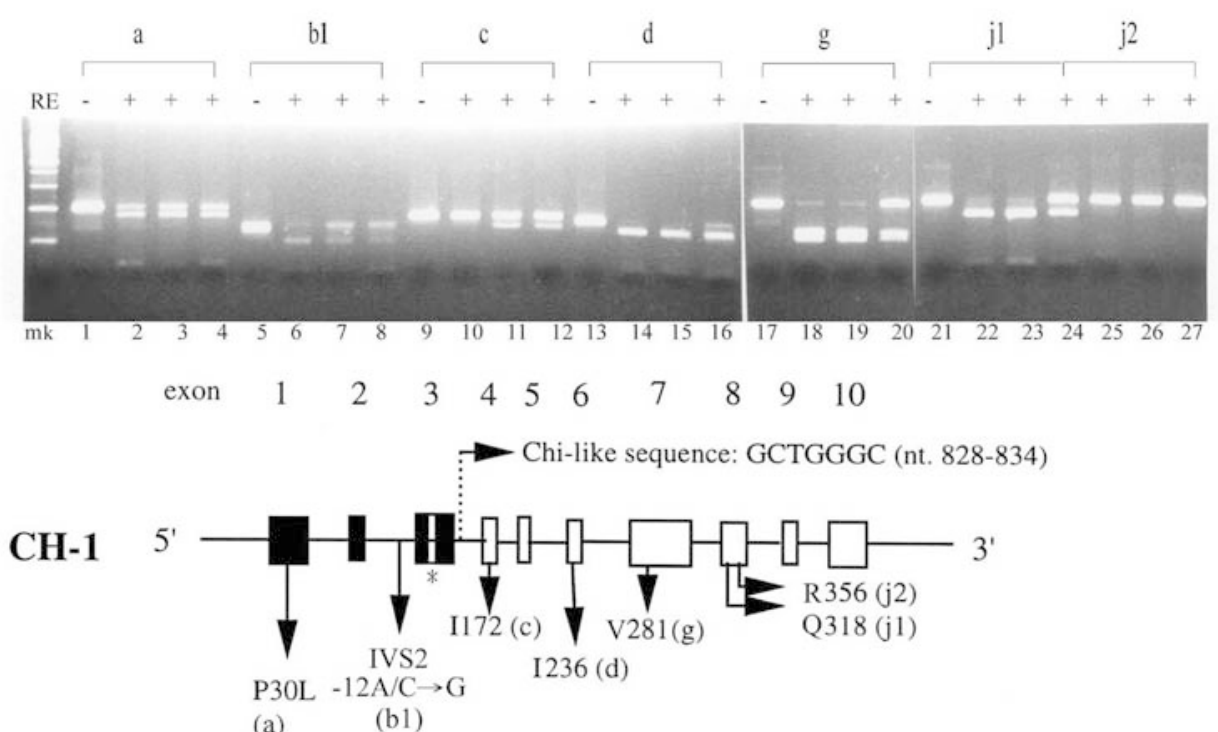

(a) (b1)
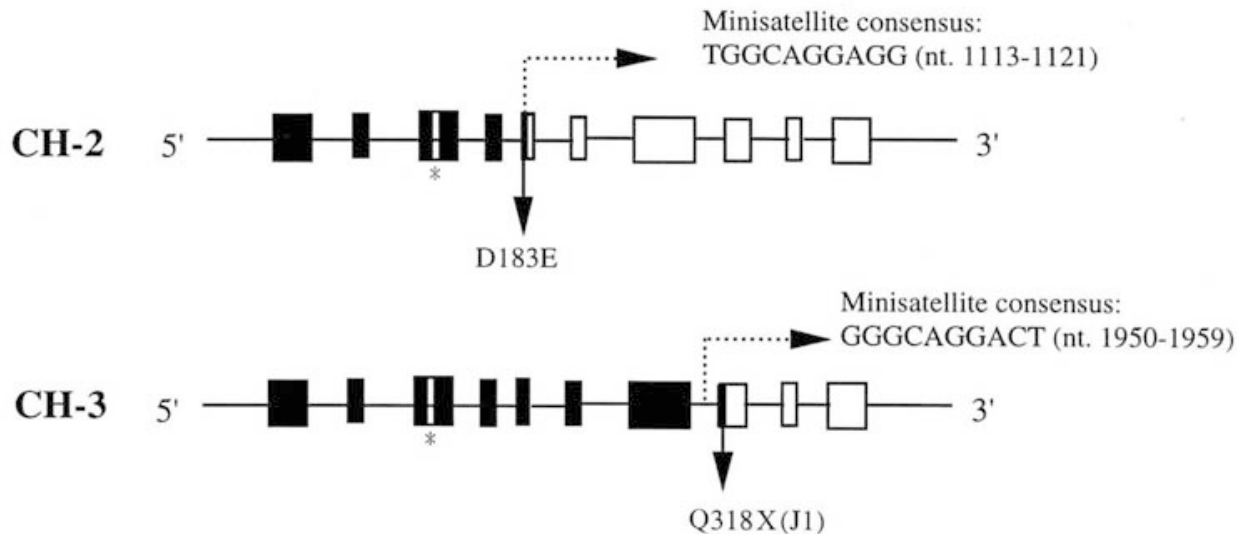
Table 1 Distribution of the chi-like sequence and minisatellite consensus in the $C Y P 21 P$ and $C Y P 21$ genes

\begin{tabular}{llc}
\hline Initiator for the chimera & \multicolumn{2}{l}{$C Y P 21 P$ and $C Y P 21$} \\
\cline { 2 - 3 } & Location & Sequence (nt) \\
\hline Chi sequence: GCTGGTGG & & \\
Chi-like sequences & & \\
GCTGGGGC & 5 ' end & -54 to -48 \\
GCTGGGGG & IVS2 & $393-400$ \\
GCTGGTCT & IVS2 & $461-468$ \\
GCTGGAGG & IVS2 & $649-642$ \\
GCTGGGCT & IVS3 & $828-835$ \\
GCTGGGGG & IVS4 & $1062-1055$ \\
GCTGGGGT & IVS5 & $1264-1271$ \\
GCTGTGGG & IVS6 & $1449-1441$ \\
GCTGGAGG & IVS7 & $1921-1928$ \\
GCTGCTGG & IVS7 & $1943-1950$ \\
GCTGGGTG & 3' end & $2830-2838$ \\
Minisatellite consensus: & & \\
GGGCAGGAXG & & $1113-1121$ \\
TGGCAGGACG & IVS4 & $1950-1959$ \\
GGGCAGGACT & IVS7 & $2710-2719$ \\
GGGCAGGACC & 3' end & \\
\hline
\end{tabular}

${ }^{\text {a }}$ Based on Higashi et al. (1986)

(GGGCAGGAXG; Jeffreys et al. 1985) are important for genetic recombination in eukaryotic cells. These sequences may be recognition sites for the recombinase complex responsible for gene recombination. It has been pointed out that the chi-like sequence GCTGGGG is present several times in the CYP21P and CYP21 gene (Table 1). Most of them appear in intron sequence. Two distinct areas of nucleotides (nt), 470-999 and 13751993 (Higashi et al. 1986), of CYP21 genes have been proposed to be related to crossover regions (Donohoue et al. 1989). On the other hand, there are three minisatellite consensus sequences located in the CYP21 gene at nt 1113-1121 (IVS4), 1950-1959 (IVS7), and the 3' untranslated region from nt 2710-2719 (Urabe et al. 1990) (Table 1). One report suggested unequal crossover in exon 7 sequences (Chu et al. 1992).

\section{Types of chimeric CYP21P/CYP21}

There have been various studies (White et al. 1988; Sinnott et al. 1990; Levo and Partanen 1997; Koppens et al. 2000) indicating hybrid genes with the $30-\mathrm{kb}$ deletion between $C Y P 21 P$ and $C Y P 21$ genes in Caucasians. Several studies (Lee et al. 2002; Lee et al. 2003a) have shown that there are three distinct chimeric $C Y P 21 P / C Y P 21 \mathrm{~s}$ in the CYP21 gene in the ethnic Chinese population in Taiwan. These three molecules are designated $\mathrm{CH}-\mathrm{I}, \mathrm{CH}-2$, and $\mathrm{CH}-3$ (Fig. 1B) (Table 2). Results indicated that $\mathrm{CH}-\mathrm{l}$ has an identical sequence to the CYP21P gene from exons 1-3 without the mutation at I172 N (nt 999) (Fig. 1B) (Table 2), $\mathrm{CH}-2$ is identical to the $C Y P 21 \mathrm{P}$ gene from exons $1-5$ of D183E (nt 1117), and $\mathrm{CH}-3$ is identical in sequence to the CYP21P gene from exons 1-8 of Q318X (nt 1994) without the R356 W mutation (Fig. 1B) (Table 2) (Lee et al. 2002; Lee et al. 2003a). In addition to these, the three chimeric $C Y P 21 P / C Y P 21 \mathrm{~s}$ possess identical 5, ends of the CYP21P gene (Table 2) (Lee et al. 2002; Lee et al. 2003a). Obviously, structural differences of the three chimeras show that these molecules are composed of unequal sequences between the $C Y P 21 P$ and $C Y P 21$ genes leading to the production of a variety of structural arrangements.

\section{Properties of the chimeric CYP21P/CYP21 gene}

Allele dropout in PCR amplification for detecting the IVS2 $-12 \mathrm{~A} / \mathrm{C}>\mathrm{G}$ mutation

As previously reported (Day et al. 1996), the allele dropout that occurs in the detection of the IVS2 $-12 \mathrm{~A} /$ $\mathrm{C}>\mathrm{G}$ mutation at nt 655 (Higashi et al 1986) is due to preferential amplification of DNA segments and is an artifact caused by polymerase (Schulze et al. 1998). This leads to an excessively high frequency of apparent homozygosity and genotyping discordance between parents and probands. A previous study (Lee et al. 2000) pointed out that allele dropout was associated with unequal amplification in the presence of the chimeric $C Y P 21 P / C Y P 21$, which lacks a specific primer for amplification during analysis of the mutation IVS2 $-12 \mathrm{~A} / \mathrm{C}>\mathrm{G}$. In addition, a recent study (Lee et al. 2003b) found that a haplotype of the $C Y P 21$ gene with the mutations of IVS2 $-12 \mathrm{~A} / \mathrm{C}>\mathrm{G}$ and 707-714delGAGACTAC (Higashi et al. 1986) is a case of gene deletion including the $C Y P 21 P, X A, R P 2$, and $C 4 B$ genes in the C4-CYP21 repeat module. This finding further confirms that allele PCR dropout in previous PCR analyses was in fact caused by the presence of the 5 ' end region of the $C Y P 21 P$ sequence, which is consistent with our previous suggestion (Lee et al. 2000). Since an antisense primer anchored at nt 707-714 of CYP21 has been used in most primary PCR amplifications (Tajima et al. 1993; Day et al. 1996; Koppens et al. 2000 ) to eliminate $C Y P 21 P$ contamination, it may have led to PCR dropout in detecting CYP21 mutations of IVS2-12A/C $>\mathrm{G}$ combined with707-714delGAGACTAC and the chimeric $C Y P 21 P / C Y P 21$.

\section{Production of a 3.2-kb fragment by Taq I digestion}

Since three chimeric $C Y P 21 P / C Y P 21$ genes contain an identical sequence in the 5' end of CYP21P (Table 2) resulting in a frameshift of the sequence upstream of CYP21P, each of the chimeras has the base $\mathrm{T}$ at $\mathrm{nt}-209$ replaced by $\mathrm{C}$ (Higashi et al. 1986) (Table 2), producing a Taq I restriction site in these defective $C Y P 21$ alleles and subsequently leading to a 3.2-kb Taq I fragment (Fig. 2A). Therefore, the assumption that the $3.2-\mathrm{kb}$ fragment from conventional Southern analysis is a deletion product of the $C Y P 21$ gene is incorrect. 
Table 2 Sequence analysis of the three chimeric $C Y P 21 P /$ $C Y P 21$ genes from ethnic Chinese congenital adrenal hyperplasia (CAH) patients. nt nucleotide, a $a$ amino acid,
Del deletion
${ }^{a}$ Based on Higashi et al. (1986)

${ }^{\mathrm{b}} \mathrm{T}$ base and ${ }^{\mathrm{c}} \mathrm{C}$ insertion are present in the normal $C Y P 21$ gene as reported by White et al. (1986) ${ }^{\mathrm{d}} \mathrm{C}-\mathrm{G}$ and ${ }^{\mathrm{e}} \mathrm{C}-\mathrm{T}$ base changes may be the breakpoint sites for $\mathrm{CH}-2$ and $\mathrm{CH}-3$ respectively

\begin{tabular}{|c|c|c|c|c|c|}
\hline \multirow{2}{*}{$\begin{array}{l}\text { Sequence } \\
\text { (nt/aa) of }\end{array}$} & \multirow[t]{2}{*}{ CYP21 } & \multirow[t]{2}{*}{$C Y P 21 P$} & \multicolumn{3}{|c|}{ Types of chimeric gene } \\
\hline & & & $\mathrm{CH}-1$ & $\mathrm{CH}-2$ & $\mathrm{CH}-3$ \\
\hline $\mathrm{nt}-306$ & G & $\mathrm{C}$ & C & $\mathrm{C}$ & C \\
\hline$-294 /-293$ & $\mathrm{~T} / \mathrm{A}$ & $\mathrm{C} / \mathrm{C}$ & $\mathrm{C} / \mathrm{C}$ & $\mathrm{C} / \mathrm{C}$ & $\mathrm{C} / \mathrm{C}$ \\
\hline-282 & A & $\mathrm{G}$ & $\mathrm{G}$ & $\mathrm{G}$ & $\mathrm{G}$ \\
\hline-209 & $\mathrm{~T}$ & $\mathrm{C}$ & $\mathrm{C}$ & $\mathrm{C}$ & $\mathrm{C}$ \\
\hline-198 & $\mathrm{C}$ & $\mathrm{T}$ & $\mathrm{T}$ & $\mathrm{T}$ & $\mathrm{T}$ \\
\hline$-188 /-189$ & - & $+\mathrm{T}$ & $+\mathrm{T}$ & $+\mathrm{T}$ & $+\mathrm{T}$ \\
\hline-126 & $\mathrm{C}$ & $\mathrm{T}$ & $\mathrm{T}$ & $\mathrm{T}$ & $\mathrm{T}$ \\
\hline-113 & G & A & A & A & A \\
\hline-110 & $\mathrm{~T}$ & $\mathrm{C}$ & $\mathrm{C}$ & $\mathrm{C}$ & $\mathrm{C}$ \\
\hline-103 & A & G & G & $\mathrm{G}$ & G \\
\hline-4 & $\mathrm{C}$ & $\mathrm{T}$ & $\mathrm{T}$ & $\mathrm{T}$ & $\mathrm{T}$ \\
\hline P10 & $P$ & $\mathrm{~L}$ & $\mathrm{~L}$ & $\mathrm{~L}$ & $\mathrm{~L}$ \\
\hline P30 & $\mathrm{P}$ & $\mathrm{L}$ & $\mathrm{L}$ & $\mathrm{L}$ & $\mathrm{L}$ \\
\hline L39 & L(TTG) & L (CTG) & $\mathrm{L}(\mathrm{CTG})$ & $\mathrm{L}(\mathrm{CTG})$ & $\mathrm{L}(\mathrm{CTG})$ \\
\hline P45 & $\mathrm{P}(\mathrm{CCA})$ & $\mathrm{P}(\mathrm{CCC})$ & $\mathrm{P}(\mathrm{CCC})$ & $\mathrm{P}(\mathrm{CCC})$ & P(CCC) \\
\hline nt 395 & $\mathrm{~T}$ & $\mathrm{C}$ & $\mathrm{C}$ & $\mathrm{T}$ & $\mathrm{C}$ \\
\hline $431 / 432$ & - & + TGTT & + TGTT & + TGTT & + TGTT \\
\hline 442 & $\mathrm{~T}$ & $\mathrm{G}$ & $\mathrm{G}$ & $\mathrm{G}$ & $\mathrm{G}$ \\
\hline 470 & A & G & G & G & G \\
\hline 478 & A & G & G & $\mathrm{G}$ & $\mathrm{G}$ \\
\hline 486 & A & G & G & G & G \\
\hline 502 & A & G & $\mathrm{A}$ & G & G \\
\hline 513 & $\mathrm{~T}$ & G & G & G & G \\
\hline 524 & $\mathrm{~T}$ & $\mathrm{C}$ & $\mathrm{C}$ & $\mathrm{C}$ & $\mathrm{C}$ \\
\hline 530 & A & $\mathrm{T}$ & $\mathrm{T}$ & $\mathrm{T}$ & $\mathrm{T}$ \\
\hline $540 / 541$ & - & $+\mathrm{TCC}$ & $+\mathrm{TCC}$ & $+\mathrm{TCC}$ & $+\mathrm{TCC}$ \\
\hline 546 & $\mathrm{C}$ & A & A & A & A \\
\hline $572-574$ & GGT & TCA & TCA & TCA & TCA \\
\hline 577 & G & A & A & A & A \\
\hline $580 / 581$ & $\mathrm{G} / \mathrm{A}$ & $\mathrm{A} / \mathrm{G}$ & $\mathrm{A} / \mathrm{G}$ & $\mathrm{A} / \mathrm{G}$ & $\mathrm{A} / \mathrm{G}$ \\
\hline 589 & G & $\mathrm{T}$ & $\mathrm{T}$ & $\mathrm{T}$ & $\mathrm{T}$ \\
\hline 594 & G & A & A & A & A \\
\hline 601 & $\mathrm{C}$ & A & A & A & A \\
\hline 620 & A & G & G & G & G \\
\hline 624 & G & $\mathrm{T}$ & $\mathrm{T}$ & $\mathrm{T}$ & $\mathrm{T}$ \\
\hline $629 / 630$ & $\mathrm{C} / \mathrm{A}$ & $\mathrm{G} / \mathrm{G}$ & $\mathrm{G} / \mathrm{G}$ & $\mathrm{G} / \mathrm{G}$ & $\mathrm{G} / \mathrm{G}$ \\
\hline 620 & A & G & $\mathrm{G}$ & $\mathrm{G}^{\prime}$ & $\mathrm{G}$ \\
\hline 655 & $\mathrm{~A} / \mathrm{C}$ & G & G & G & G \\
\hline $\mathrm{S} 108$ & $\mathrm{~S}(\mathrm{TCC})$ & $\mathrm{S}(\mathrm{TCG})$ & $\mathrm{S}(\mathrm{TCG})$ & $\mathrm{S}(\mathrm{TCG})$ & $\mathrm{S}(\mathrm{TCG})$ \\
\hline G110 & $\mathrm{G}(\mathrm{GGA})$ & G110delGA & G110delGA & G110delGA & G110delGA \\
\hline D111 & $\mathrm{D}$ & Del & Del & Del & Del \\
\hline Y112 & Y & Del & Del & Del & Del \\
\hline $\mathrm{S} 113$ & $\mathrm{~S}(\mathrm{TCC})$ & $\mathrm{S}(\mathrm{TCT})$ & $\mathrm{S}(\mathrm{TCT})$ & $\mathrm{S}(\mathrm{TCT})$ & $\mathrm{S}(\mathrm{TCT})$ \\
\hline nt 860 & $\mathrm{C}$ & $\mathrm{C}$ & $\mathrm{T}^{\mathrm{b}}$ & $\mathrm{C}$ & $\mathrm{C}$ \\
\hline $886-890$ & CCGCT & CCGCT & $\mathrm{CCCGCT}^{\mathrm{c}}$ & CCCGCT & CCCGCT \\
\hline I172 & I & $\mathrm{N}$ & I & $\mathrm{N}$ & $\mathrm{N}$ \\
\hline nt 1104 & $\mathrm{C}$ & A & $\mathrm{C}$ & $\mathrm{C}$ & A \\
\hline 1111 & $\mathrm{~T}$ & $\mathrm{C}$ & $\mathrm{T}$ & $\mathrm{C}$ & $\mathrm{C}$ \\
\hline D183 & $\mathrm{D}(\mathrm{GAC})$ & $\mathrm{E}(\mathrm{GAG})$ & $\mathrm{D}(\mathrm{GAC})$ & $\mathrm{E}(\mathrm{GAG})^{\mathrm{d}}$ & GAG \\
\hline D234 & $\mathrm{D}(\mathrm{GAT})$ & $\mathrm{D}(\mathrm{GAC})$ & $\mathrm{D}(\mathrm{GAT})$ & $\mathrm{D}(\mathrm{GAT})$ & GAC \\
\hline $\mathrm{I} 236$ & I & $\mathrm{N}$ & I & I & $\mathrm{N}$ \\
\hline V237 & V & $\mathrm{E}$ & V & V & $\mathrm{E}$ \\
\hline M239 & $\mathrm{M}$ & $\mathrm{K}$ & $\mathrm{M}$ & $\mathrm{M}$ & $\mathrm{K}$ \\
\hline nt $1420 / 1421$ & $\mathrm{AC}$ & GT & $\mathrm{AC}$ & $\mathrm{AC}$ & GT \\
\hline L248 & $\mathrm{L}(\mathrm{CTC})$ & L(CTG) & $\mathrm{CTC}$ & CTC & CTG \\
\hline V281 & $\mathrm{V}$ & $\mathrm{L}$ & $\mathrm{V}$ & $\mathrm{V}$ & $\mathrm{L}$ \\
\hline F306-L307 & - & ins T & - & - & insT \\
\hline nt 1789 & G & $\mathrm{C}$ & G & G & $\mathrm{C}$ \\
\hline Q318X & $\mathrm{Q}(\mathrm{CAG})$ & X(TAG) & $\mathrm{Q}$ & $\mathrm{Q}$ & $\mathrm{X}^{\mathrm{e}}$ \\
\hline R356W & $\mathrm{R}$ & W & $\mathrm{W}$ & W & $\mathrm{W}$ \\
\hline
\end{tabular}


Production of a 9.3-kb fragment resulting from deletion of the $T N X A, R P 2$, and $C 4 B$ genes

In the traditional Southern blot analysis, Taq I generates a $3.7-\mathrm{kb}$ (functional) and a $3.2-\mathrm{kb}$ (pseudogene) fragment, and $B g l$ II produces an $11-\mathrm{kb}$ (functional) and a $12-\mathrm{kb}$ (pseudogene) fragment, which cannot indicate detailed information on the extent of gene conversion or deletion in the RCCX module. Therefore, a study (Lee et al. 2003a) using two restriction endonucleases, Ase I and $N d e \mathrm{I}$, with a single probe was used to identify the interchange region. Results revealed that deletion of the $T N X A, R P 2$, and $C 4 B$ genes (Fig. 1A) leads to formation of the chimeric $C Y P 21 P / C Y P 21$ in a $9.3-\mathrm{kb}$ fragment (Fig. 2B, lane $M$ ). This improves the detection protocol for gene deletions and conversions in the RCCX module (Fig. 1A). Given the potential for variations and a lack of information about the $C 4 B$ gene (Yu 1991) in Chinese populations, the size of the RCCX modular deletion may either be 26 or $32 \mathrm{~kb}$ long (Fig. 1A) (Lee et al. 2003a).

\section{Biological activity of the chimeric $C Y P 21 P / C Y P 21$}

Because the 5' end of the three different chimeric $C Y P 21 P / C Y P 21$ genes have identical sequences with that of $C Y P 21 P$ (Table 2), nucleotide substitutions at these sites from $C Y P 21 P$ - to $C Y P 21$-specific sequences at $\mathrm{nt}-103,-110$, and -123 (Higashi et al. 1986) cause a five-fold decrease in transcriptional activity and in the ability of the promoter to bind with the $\mathrm{Sp} 1$ protein (Chang and Chung 1995). At nt 655 (Higashi et al. 1986)
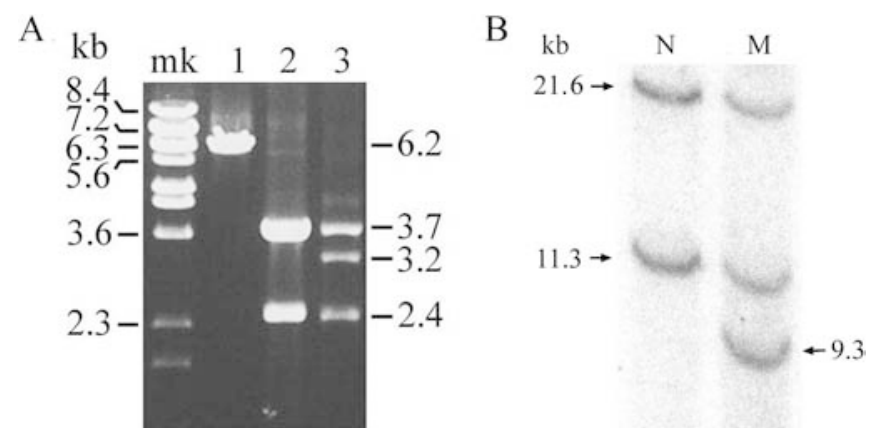

Fig. 2 A Analysis of the $6.2-\mathrm{kb}$ PCR product by $T a q$ I digestion on a $0.65 \%$ agarose gel. Lane 1 : the $6.2-\mathrm{kb}$ PCR product amplified with paired primers Tena36F2/CYP779f from a normal individual. Lanes 2 and 3 are the 6.2-kb PCR product digested by Taq I from a normal individual and a congenital adrenal hyperplasia $(\mathrm{CAH})$ patient with $\mathrm{CH}-\mathrm{l}$ chimera in one of the chromosomes respectively. " $m k$ " was a Lambda DNA-BstE II-digested molecular marker (New England BioLabs, Beverly, MA, USA). B Southern blot analysis of Ase I and Nde I digestion of genomic DNA. The hybridization probe used consisted of the 2271-bp PCR product derived using the paired primers Tena36F2/Tena43R (Lee et al. 2003a). A normal individual (lane $N$ ) had two fragments of 11.3 and $21.6 \mathrm{~kb}$, and one patient with a $\mathrm{CH}-1$ chimera in one of the chromosomes (lane $M$ ) had an additional $9.3-\mathrm{kb}$ fragment as well as having the 11.3- and $21.6-\mathrm{kb}$ fragments of the IVS2 $-12 \mathrm{~A} / \mathrm{C}>\mathrm{G}$ mutation, the aberrant splicing site results in very low but measurable enzyme levels (Higashi et al. 1988a). In addition, deletion of 707-714delGAGACTAC leads to a frameshift mutation, which forms a TGA stop codon downstream at nt 830 (Higashi et al. 1986) and produces a truncated protein in translation. Taken together, these three kinds of chimeric $C Y P 21 P / C Y P 21$ have no steroid 21-hydroxylase activity. However, the hybrid gene reported by the study (L'Allemand et al. 2000) without these two mutations had low 21-hydroxylase activity with a defect in P30L.

\section{Identification of the chimeric CYP21P/CYP21 gene}

Identification of gene deletions and conversions is still being studied by Southern blot analysis with oligonucleotides (Higashi et al 1988b; Donohoue et al. 1989; Helmberg et al. 1992; Tusie-Luna and White 1995) or DNA probes (Krone et al. 1998; Koppens et al. 2000; L'Allemand et al. 2000) for hybridization. There are two established strategies of PCR amplification for identifying the $C Y P 21$ gene:

1. Mixed-primer amplification of the 3.5-kb PCR product: To collect the chimeric $C Y P 21 P / C Y P 21$, three primers (Table 3) containing a 3'-specific primer for the $C Y P 21$ gene and two different 5'-primers for both $C Y P 21$ and $C Y P 21 P$ used to amplify the normal $C Y P 21$, and the chimera have been successfully used for $\mathrm{CAH}$ diagnosis (Lee et al. 2000; 2002). The 3.5-kb fragments (Lee et al. 2000 ; 2002) covering sequences of the CYP21 gene from -313 to 3170 (Higashi et al. 1986) were generated. The PCR products were analyzed using the ACRS primer for mutational analysis (Fig. 1B) (Lee et al. 1996).

2. The 6.2-kb PCR product encompassing the $T N X B$ gene to the 3'-end of the $C Y P 21$ gene: In order to understand the status of the $C Y P 21$ gene within the RCCX module after gene deletion or conversion, a strategy of using a $6.2-\mathrm{kb}$ PCR product amplified with locus-specific primers from the tenascin $(T N X B)$ gene to the 5' end of $C Y P 21 P$ or $C Y P 21$ has been successfully achieved (Figs. 1C, 2A) (Lee et al. 2003a,2003b). The sense primer located in tenascin B $(T N X B)$ containing a 120-bp sequence deleted from tenascin $\mathrm{A}(T N X A)$ and an antisense primer in the 5, end of the $C Y P 21 P$ and $C Y P 21$ genes were used (Table 3) (Fig. 1C). The 6.2-kb PCR product was further identified either by the ACRS primer to detect CYP21 mutations (Fig. 1B) (Lee et al.1996) or by $\mathrm{Taq}$ I digestion directly analyzed on an agarose gel to evaluate the 3.2- and 3.7-kb fragments (Fig. 2A).

\section{Conclusions}

Questions regarding gross gene deletion of $30 \mathrm{~kb}$ encompassing the $C 4 A$ and $C Y P 21$ genes have arisen 
Table 3 Primers for the amplification of chimeric $C Y P 21 P / C Y P 21$ gene

\begin{tabular}{|c|c|c|c|}
\hline Primer & Sequence $\left(5^{\prime}>3^{\prime}\right)$ & Location & Specificity \\
\hline \multicolumn{4}{|c|}{ Mixed primers for $3.5-\mathrm{kb}$ PCR product amplification ${ }^{\mathrm{a}}$} \\
\hline $21 \mathrm{BF} 1$ & CCCAGGTGGGGGCGGACACTA & -314 to $-294^{\mathrm{b}}$ & CYP21 \\
\hline 21BR & ААТTAAGCСТСААТССТСТGCAGCG & $3177-3153$ & CYP21 \\
\hline \multicolumn{4}{|c|}{ Primers for $6.2-\mathrm{kb}$ PCR product amplification $^{\mathrm{c}}$} \\
\hline Tena $36 \mathrm{~F} 2$ & AGGCGCTCGCTATGAGGTGAC & $81,255-81,275^{\mathrm{d}}$ & $T N X B$ \\
\hline CYP779f & AGGTGGGCTGTTTTCCTTTCA & $87,443-87,463$ & CYP21P/CYP21 \\
\hline
\end{tabular}

${ }^{\mathrm{a}}$ Protocol for the amplification of 3.5-kb PCR product was previously reported (Lee et al. 2000; Lee 2001) ${ }^{\mathrm{b}}$ Based on that published by Higashi et al. (1986) ${ }^{\mathrm{c}}$ Protocol for the amplification of the 6.2-kb (Tena36F2/CYP779f) PCR product was previously published (Lee et al. 2003b) ${ }^{\mathrm{d}}$ Based on GenBank accession no. AL049547

because there is no information on the deleted region in the RCCX module. The chimeric $C Y P 21 P / C Y P 21$ is a consequence of the deletion of the complete $X A, R P 2$, and $C 4 B$, and partial $C Y P 21 P / C Y P 21$ genes of 26 or $32 \mathrm{~kb}$, depending on whether $C 4 B$ is a long or short gene. Therefore, presentation of a $3.2-\mathrm{kb}$ fragment produced by $T a q$ I digestion is not only a single $C Y P 21$ deletion but there is also a chimera included. A previous strategy (Krone et al. 1998) using the Taq I restriction enzyme was applied to specifically disrupt the $C Y P 21 P$ gene for identification of the $C Y P 21$ mutation, which may possibly cause a loss of amplification of the chimera. Results of a recent study (Lee et al. 2003b) indicated that the haplotype of the $C Y P 21$ allele with the mutation IVS2-12A/C $>\mathrm{G}$ combined with 707-714delGAGACTAC is not a chimeric $C Y P 21 P / C Y P 21$ gene but does show a $3.2-\mathrm{kb}$ fragment by $T a q$ I digestion. Therefore, we believe that the diversity of haplotypes of the CYP21 allele with the $3.2-\mathrm{kb}$ fragment may frequently occur in $\mathrm{CAH}$ patients with steroid 21-hydroxylase deficiency.

Acknowledgements The author thanks Drs. H.T. Chao, Y.J. Lee, F.S. Lo, M.C. Chao, D.M. Nu, S.J. Lin, F.J. Tsai, and L.P. Tsai for donating blood samples of Taiwanese CAH patients from 1994 to the present. This work was supported by King Car Research Foundation from the King Car Food Industrial Co., Taiwan, Republic of China.

\section{References}

Bristow J, Tee MK, Gitelman SE, Mellon SH, Miller WL (1993) Tenascin-X: a novel extracellular matrix protein encoded by the human XB gene overlapping P450c21B. J Cell Biol 122:265-278

Chang SF, Chung Bc (1995) Difference in transcriptional activity of two homologous $C Y P 21 A$ genes. Mol Endocrinol 9:1330-1336

Chu X, Braun-Heimer L, Rittner C, Schneider PM (1992) Identification of the recombination site within the steroid 21hydroxylase gene (CYP21) of the HLA-B47, DR7 haplotype. Exp Clin Immunogenet 9:80-85

Collier S, Sinnott PJ, Dyer PA, Price DA, Harris R, Strachan T (1989) Pulsed field gel electrophoresis identifies a high degree of variability in the number of tandem 21-hydroxylase and complement $\mathrm{C} 4$ gene repeats in 21-hydroxylase deficiency haplotypes. EMBO J 8:1393-1402

Day DJ, Speiser PW, White PC, Barany F (1995) Detection of steroid 21-hydroxylase alleles using gene-specific PCR and a multiplexed ligation detection reaction. Genomics 29:152-162
Day DJ, Speiser PW, Schulze E, Bettendorf M, Fitness J, Barany F, White PC (1996) Identification of non-amplifying CYP21 genes when using PCR-based diagnosis of 21-hydroxylase deficiency in congenital adrenal hyperplasia $(\mathrm{CAH})$ affected pedigrees. Hum Mol Genet 5:2039-2048

Donohoue PA, Jospe N, Migeon CJ, Van Dop C (1989) Two distinct areas of unequal crossing over within the steroid 21hydroxylase genes produce absence of CYP21B. Genomics 5:397-406

Gitelman SE, Bristow J, Miller WL (1992) Mechanism and consequences of the duplication of the human $\mathrm{C} 4 / \mathrm{P} 450 \mathrm{c} 21 /$ gene $\mathrm{X}$ locus. Mol Cell Biol 12:2124-2134

Helmberg A, Tabarelli M, Fuchs MA, Keller E, Dobler G, Schnegg I, Knorr D, Albert E, Kofler R (1992) Identification of molecular defects causing congenital adrenal hyperplasia by cloning and differential hybridization of polymerase chain reaction-amplified 21-hydroxylase (CYP21) genes. DNA Cell Biol 11:359-368

Higashi Y, Yoshioka H, Yamane M, Gotoh O, Fujii-Kuriyama Y (1986) Complete nucleotide sequence of two steroid 21hydroxylase genes tandemly arranged in human chromosome: a pseudogene and a genuine gene. Proc Natl Acad Sci USA 83:2841-2845

Higashi $\mathrm{Y}$, Tanae A, Inoue $\mathrm{H}$, Hiromasa T, Fujii-Kuriyama $\mathrm{Y}$ (1988a) Aberrant splicing and missense mutations cause steroid 21-hydroxylase [P-450(C21)] deficiency in humans: possible gene conversion products. Proc Natl Acad Sci USA 85:74867490

Higashi Y, Tanae A, Inoue H, Fujii-Kuriyama Y (1988b) Evidence for frequent gene conversion in the steroid 21-hydroxylase P-450 (C21) gene: implications for steroid 21-hydroxylase deficiency. Am J Hum Genet 42:17-25

Human Gene Mutation Database (2003)http://uwcmmlls.uwcm.ac.uk/uwcm/mg/search/120605.html. Cited Oct. 2003

Jeffreys AJ, Wilson V, Thein SL (1985) Hypervariable 'minisatellite' regions in human DNA. Nature 314:67-73

Koppens PF, Hoogenboezem T, Degenhart HJ (2000) CYP21 and CYP21P variability in steroid 21-hydroxylase deficiency patients and in the general population in the Netherlands. Eur $\mathbf{J}$ Hum Genet 8:827-836

Krone N, Roscher AA, Schwarz HP, Braun A (1998) Comprehensive analytical strategy for mutation screening in 21hydroxylase deficiency. Clin Chem 44:2075-2082

L'Allemand D, Tardy V, Gruters A, Schnabel D, Krude H, Morel Y. (2000) How a patient homozygous for a $30-\mathrm{kb}$ deletion of the C4-CYP21 genomic region can have a nonclassic form of 21 hydroxylase deficiency. J Clin Endocrinol Metab 85:4562-4567

Lee HH (2001) CYP21 mutations and congenital adrenal hyperplasia. Clin Genet 59:293-301

Lee HH, Chang SF (2001) Multiple transcripts of the CYP21 gene are generated by the mutation of the splicing donor site in intron 2 from GT to AT in 21-hydroxylase deficiency. J Endocrinol 171:397-402

Lee HH, Chao HT, Ng HT, Choo KB (1996) Direct molecular diagnosis of $C Y P 21$ mutations in congenital adrenal hyperplasia. J Med Genet 33:371-375 
Lee HH, Chao HT, Lee YJ, Shu SG, Chao MC, Kuo JM, Chung Bc (1998) Identification of four novel mutations in the CYP21 gene in congenital adrenal hyperplasia in the Chinese. Hum Genet 103:304-310

Lee HH, Chang JG, Tsai CH, Tsai FJ, Chao HT, Chung Bc (2000) Analysis of the chimeric $C Y P 21 P / C Y P 21$ gene in steroid 21hydroxylase deficiency. Clin Chem 46:606-611

Lee HH, Niu DM, Lin RW, Chan P, Lin CY (2002) Structural analysis of the chimeric $C Y P 21 P / C Y P 21$ gene in steroid 21hydroxylase deficiency. J Hum Genet 47:517-522

Lee HH, Chang SF, Lee YJ, Raskin S, Lin SJ, Chao MC, Lo FS, Lin CY (2003a) Deletion of the C4-CYP21 repeat module leading to the formation of a chimeric $C Y P 21 P / C Y P 21$ gene in a $9.3-\mathrm{kb}$ fragment as a cause of steroid 21-hydroxylase deficiency. Clin Chem 49:319-322

Lee HH, Chang SF, Tsai FJ, Tsai LP, Lin CY (2003b) Mutation of IVS2 -12 A/C- $>\mathrm{G}$ in combination with 707-714delGAGACTAC in the CYP21 gene is caused by deletion of the C4-CYP21 repeat module with steroid 21-hydroxylase deficiency. J Clin Endocrinol Metab 88:2726-2729

Levo A, Partanen J (1997) Mutation-haplotype analysis of steroid 21-hydroxylase (CYP21) deficiency in Finland. Implications for the population history of defective alleles. Hum Genet 99:488497

Miller WL (1988) Gene conversions, deletions, and polymorphisms in congenital adrenal hyperplasia. Am J Hum Genet 42:4-7

Morel Y, David M, Forest MG, Betuel H, Hauptman G, Andre J, Bertrand J, Miller WL (1989) Gene conversions and rearrangements cause discordance between inheritance of forms of 21-hydroxylase deficiency and HLA types. J Clin Endocrinol Metab 68:592-599

Ohlsson G, Muller J, Schwartz M (1999) Genetic diagnosis of 21hydroxylase deficiency: DGGE-based mutation scanning of CYP21. Hum Mutat 13:385-389

Ordonez-Sanchez ML, Ramirez-Jimenez S, Lopez-Gutierrez AU, Riba L, Gamboa-Cardiel S, Cerrillo-Hinojosa M, AltamiranoBustamante N, Calzada-Leon R, Robles-Valdes C, MendozaMorfin F, Tusie-Luna MT (1998) Molecular genetic analysis of patients carrying steroid 21-hydroxylase deficiency in the Mexican population: identification of possible new mutations and high prevalence of the apparent germ-line mutations. Hum Genet 102:170-177

Schulze E, Bettendorf M, Maser-Gluth C, Decker M, Schwabe U (1998) Allele-dropout using PCR-based diagnosis for the splicing mutation in intron-2 of the CYP21B-gene: successful amplification with a Taq/Pwo-polymerase mixture. Endocr Res 24:637-641

Shen L, Wu LC, Sanlioglu S, Chen R, Mendoza AR, Dangel AW, Carroll MC, Zipf WB, Yu CY (1994) Structure and genetics of the partially duplicated gene RP located immediately upstream of the complement C4A and the C4B genes in the HLA class III region. Molecular cloning, exon-intron structure, composition retroposon, and breakpoint of gene duplication. J Biol Chem 269:8466-8476
Sinnott P, Collier S, Costigan C, Dyer PA, Harris R, Strachan T (1990) Genesis by meiotic unequal crossover of a de novo deletion that contributes to steroid 21-hydroxylase deficiency. Proc Natl Acad Sci USA 87:2107-2111

Smith GR, Kunes SM, Schultz DW, Taylor A, Triman KL (1981) Structure of chi hotspots of generalized recombination. Cell 24:429-436

Speiser PW, White PC, Dupont J, Zhu D, Mercado AB, New MI (1994) Prenatal diagnosis of congenital adrenal hyperplasia due to 21-hydroxylase deficiency by allele-specific hybridization and southern blot. Hum Genet 93:424-428

Tajima T, Fujieda K, Nakayama K, Fujii-Kuriyama Y (1993) Molecular analysis of patient and carrier genes with congenital steroid 21-hydroxylase deficiency by using polymerase chain reaction and single strand conformation polymorphism. J Clin Invest 92:2182-2190

Tusie-Luna MT, White PC (1995) Gene conversions and unequal crossovers between CYP21 (steroid 21-hydroxylase gene) and CYP21P involve different mechanisms. Proc Natl Acad Sci USA 92:10796-10800

Urabe K, Kimura A, Harada F, Iwanaga T, Sasazuki T (1990) Gene conversion in steroid 21-hydroxylase genes. Am J Hum Genet 46:1178-1186

White PC, New MI, Dupont B (1984) HLA-linked congenital adrenal hyperplasia results from a defective gene encoding a cytochrome P-450 specific for steroid 21-hydroxylation. Proc Natl Acad Sci USA 81:7505-7509

White PC, New MI, Dupont B (1986) Structure of human steroid 21-hydroxylase genes. Proc Natl Acad Sci USA 83:5111-5115

White PC, Vitek A, Dupont B, New MI (1988) Characterization of frequent deletions causing steroid 21-hydrxylase deficiency. Proc Natl Acad Sci USA 85:4436-4440

White PC, Speiser PW (2000) Congenital adrenal hyperplasia due to 21-hydroxylase deficiency. Endocr Rev 21:245-291

Yang Z, Shen L, Dangel AW, Wu LC, Yu CY (1998) Four ubiquitously expressed genes, $R D$ (D6S45)-SK12W-(SKIV2L)DOM 3Z-RP1(D6S60E), are present between complement component genes factor B and $\mathrm{C} 4$ in the class III region of the HLA. Genomics 53:338-347

Yang Z, Mendoza AR, Welch TR, Zipf WB, Yu CY (1999) Modular variations of the human major histocompatibility complex class III genes for serine/threonine kinase RP, complement component $\mathrm{C} 4$, steroid 21-hydroxylase CYP21, and tenascin TNX (the RCCX module). A mechanism for gene deletion and disease associations. J Biol Chem 274:12147-12156

Yang YP, Corley N, Garcia-Heras J (2001) Reverse dot-blot hybridization as an improved tool for the molecular diagnosis of point mutations in congenital adrenal hyperplasia caused by 21-hydroxylase deficiency. Mol Diagn 6:193-199

Yu CY (1991) The complete exon-intron structure of a human complement component C4A gene. DNA sequences, polymorphism, and linkage to the 21-hydroxylase genes. J Immunol 146:1057-1066 